Paweł Pisany

ORCID: 0000-0001-9665-8840

Instytut Nauk Ekonomicznych Polskiej Akademii Nauk

https://doi.org/10.19195/1733-5779.33.19

\title{
Lekcje płynące $z$ historii gospodarczej — kryzys azjatycki z 1997 roku a aktualna potrzeba rozwoju źródeł finansowania w walucie krajowej od rezydentów
}

JEL Classification: G15, G21, O53

Słowa kluczowe: kryzys, sektor bankowy, Azja

Keywords: crisis, banking sector, Asia

Abstrakt: Kryzys azjatycki z 1997 roku stanowi cenne źródło doświadczeń dla gospodarek wschodzących jeśli chodzi o rolę systemu finansowego w fazie szybkiego rozwoju gospodarczego. W niniejszym opracowaniu analizie poddano wydarzenia kryzysowe z 1997 roku w kontekście pożądanego kierunku rozwoju systemu finansowego. Podjęte badania wskazują, że cechą charakterystyczną finansowania dłużnego w gospodarkach azjatyckich przed 1997 rokiem było rosnące podwójne niedopasowanie bilansowe (double mismatch dillema), to jest dotyczące terminów wymagalności oraz waluty pozyskiwanego finansowania. Błędem było oparcie wzrostu gospodarczego na zagranicznym krótkoterminowym finansowaniu nominowanym w walutach obcych. Studia nad kryzysem azjatyckim wskazują, że odpowiednio rozwinięte krajowe rynki finansowe powinny stanowić konkurencję wobec zagranicznych, zwłaszcza w gospodarkach wschodzących, a dywersyfikacja finansowania gospodarki, jeśli chodzi o pochodzenie środków (krajowe lub zagraniczne), może stanowić narzędzie wydłużenia terminów wymagalności pożyczek oraz redukcji niedopasowania walutowego oraz w konsekwencji zwiększać odporność gospodarki na szoki zewnętrzne.

\section{Lessons from economic history — the Asian crisis of 1997 and the need to develop financing in local currency from residents}

\begin{abstract}
The Asian crisis of 1997 is a valuable source of experience for emerging economies regarding the role of the financial system in the phase of rapid economic growth. This study analyzes the Asian crisis of 1997 in the context of directions of development of the desired financial system. The research indicates that an important characteristic of debt financing in Asian economies before 1997 was the so-called double mismatch dilemma, i.e. regarding maturity and currency of the
\end{abstract}


financing obtained. Economic growth was based on foreign short-term financing denominated in foreign currencies, which proved to be the wrong strategy. Studies on the Asian crisis indicate that properly developed domestic financial markets should compete with foreign ones, especially in emerging economies. Furthermore, diversifying the financing of the economy regarding the origin of funds (domestic or foreign) can be a tool for extending loans maturities and reducing currency mismatch and, as a consequence, increasing the economy's resistance to external shocks.

\section{Cel opracowania}

Celem niniejszego artykułu jest analiza oraz interpretacja kryzysu azjatyckiego z 1997 roku w kontekście pożądanego kierunku rozwoju systemu finansowego, zwłaszcza w gospodarkach wschodzących. W opracowaniu przedstawione zostaną: historia kryzysu, dwa główne, obecne w debacie ekonomicznej, nurty interpretacji przyczyn kryzysu, analiza cech załamania gospodarczego w krajach azjatyckich z 1997 roku oraz wnioski.

\section{Azjatycki kryzys finansowy z 1997 roku}

Azjatycki kryzys finansowy z 1997 roku miał istotny wpływ na wiele gospodarek regionu. Szczególnie dotknięte nim zostały cztery kraje — Indonezja, Korea Południowa, Malezja i Tajlandia ${ }^{1}$. Niektórzy badacze ${ }^{2}$ wskazują, że w trzech z wymienionych państw, to jest Indonezji, Korei Południowej oraz Tajlandii, kryzys był jednym z czynników, które doprowadziły do zmian rządów. Wykresy 1 oraz 2 prezentujące zmiany PKB w cenach stałych w krajach azjatyckich wskazują na kraje najbardziej dotknięte recesją gospodarczą w latach 1997-1998.

Ponadto na wykresach 1 oraz 2 widać, że zarówno odnośnie do PKB całkowitego, jak i w ujęciu PKB na mieszkańca kryzys azjatycki z 1997 roku był głębszym szokiem w wielu krajach azjatyckich niż globalny kryzys finansowy z lat 2008-2009. W 1998 roku osiem z dziesięciu krajów badanych w niniejszej rozprawie (poza Chinami i Wietnamem) odnotowało ujemne tempo wzrostu PKB (wykres 1). Kraje wskazywane w literaturze ${ }^{3}$ jako najbardziej dotknięte kryzysem, to jest Tajlandia, Indonezja, Malezja, Korea Południowa, doświadczyły w 1998 roku spadków PKB na poziomie odpowiednio 7,7\%, 13,1\%, 7,4\% oraz 5,5\%. Filipiny — gospodarka również dotknięta atakiem spekulacyjnym na walutę krajową odnotowały relatywnie mniejsze załamanie gospodarcze. Spadek PKB w 1998 roku wyniósł $0,6 \%$.

Już od początku 1997 roku pojawiły się sygnały wycofywania kapitału z krajów azjatyckich przez zagranicznych inwestorów. Początkowo dotyczyło to Taj-

${ }^{1}$ K. Hoe Ee, K. Wei Zheng, Ten years from the financial crisis. Managing the challenges posed by capital flows, [w:] Lessons from the Asian Financial Crisis, red. R. Carney, New York 2008, s. 84-111.

2 J. Lai, Financial Crisis and Institutional Change in East Asia, London 2012.

${ }^{3}$ K. Hoe Ee, K. Wei Zheng, op. cit., s. 84-111. 


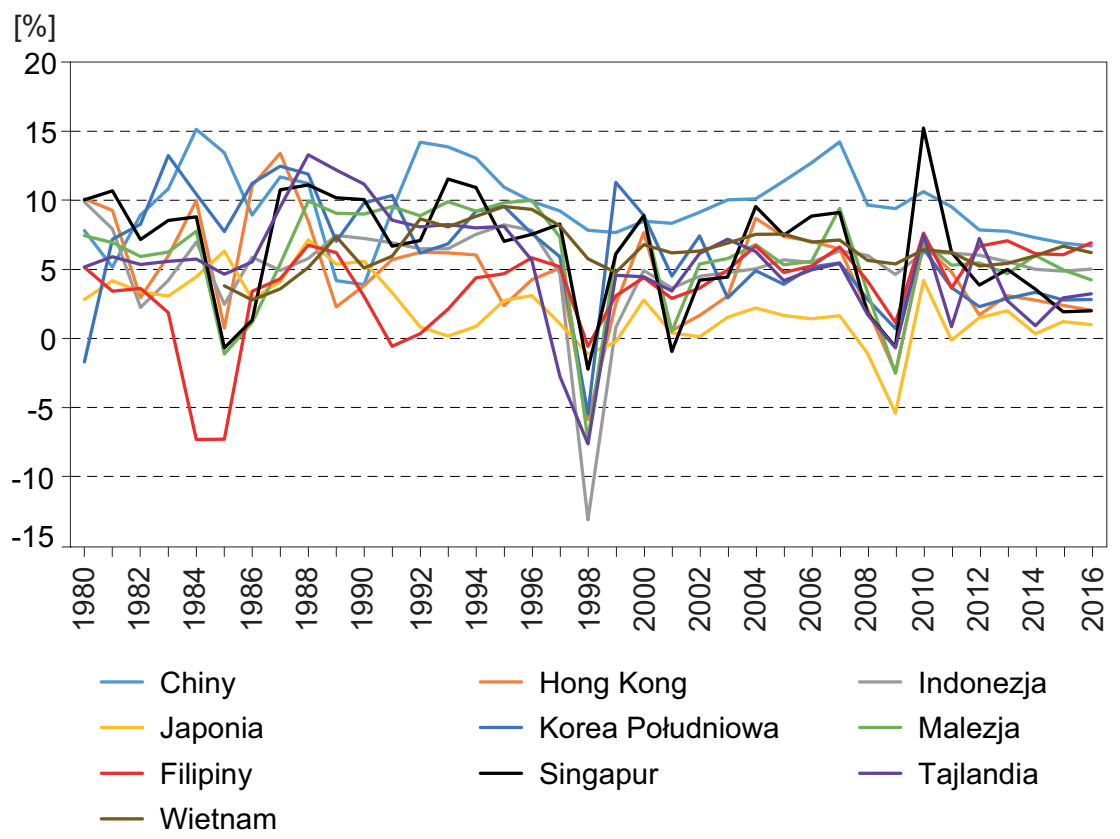

Wykres 1. Wzrost PKB w wybranych krajach azjatyckich; PKB w cenach stałych Źródło: Bank Światowy.

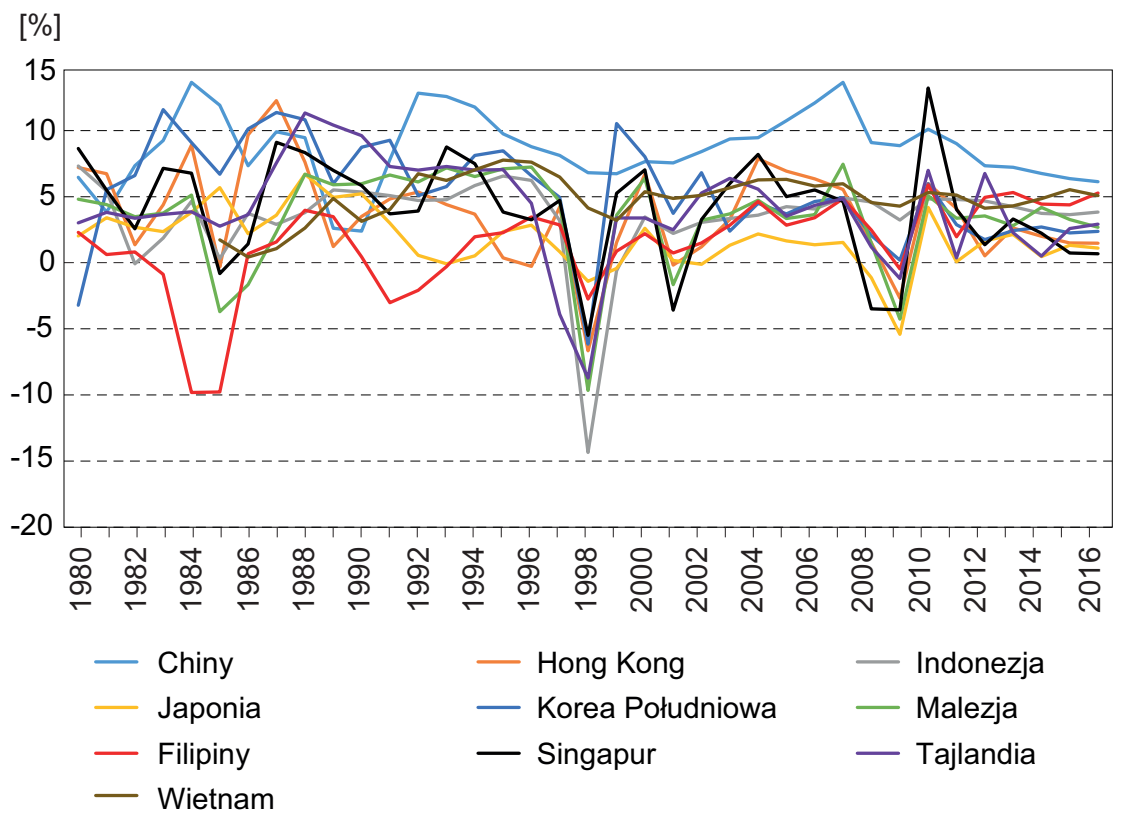

Wykres 2. Wzrost PKB per capita w wybranych krajach azjatyckich; PKB w cenach stałych Źródło: Bank Światowy. 
landii i było związane z pogarszającą się sytuacją finansową sektora realnego, w szczególności upadkiem kilku deweloperów oraz słabszymi niż oczekiwano wynikami eksportu tajlandzkiego. Jednocześnie wiosną 1997 roku podniesiono stopy procentowe w gospodarkach rozwiniętych — Wielkiej Brytanii i Niemczech — oraz pojawiły się oczekiwania odnośnie do podwyżki stóp w Japonii. Bank centralny Tajlandii starał się interweniować w celu obrony kursu waluty krajowej (bahta). Łącznie wprowadził na rynek finansowy 23 mld USD w różnych walutach obcych w ramach interwencji. Cały zasób rezerw w posiadaniu tajlandzkiego banku centralnego wynosił wtedy 25 mld USD. Niemożność skutecznej obrony bahta zmusiła władze Tajlandii do uwolnienia kursu walutowego. Nastąpiło to 2 lipca 1997 roku i stało się początkiem silnej deprecjacji waluty tajlandzkiej i kryzysu walutowego ${ }^{4}$.

Decyzja banku centralnego Tajlandii o uwolnieniu kursu walutowego spowodowała, że pojawiły się wśród inwestorów oczekiwania dotyczące porzucenia reżimów sztywnych kursów walutowych przez inne kraje regionu. Dlatego też między lipcem a październikiem 1997 roku nastąpiły ataki spekulacyjne na waluty kolejno Filipin, Malezji oraz Indonezji. We wszystkich trzech przypadkach po nieudanych interwencjach walutowych uwolniono kursy walut krajowych ${ }^{5}$. W tym czasie rządy wymienionych krajów zwróciły się o pomoc do Międzynarodowego Funduszu Walutowego (dalej: MFW). Program opracowany przez MFW zawierał między innymi: usunięcie z rynku nierentownych banków, podniesienie wymogów kapitałowych w sektorze bankowym, restrykcyjną politykę pieniężną (politykę wysokich stóp procentowych) oraz restrykcyjną politykę fiskalną (cięcia budżetowe). Działania te były w istocie procykliczne i ich bezpośrednim następstwem było pogłębienie się kryzysu w wymienionych gospodarkach ${ }^{6}$. Kolejne kroki MFW zostały już poddane korekcie. Następnie kryzys przeniósł się do gospodarki koreańskiej. Jego skutki odczuły także inne kraje azjatyckie (na przykład Tajwan, Singapur, Hongkong), a także odległe geograficznie gospodarki wschodzące (na przykład Czechy i Słowacja). Z punktu widzenia niniejszego opracowania intersujące są źródła załamania gospodarczego z 1997 roku oraz potencjalna możliwość zwiększenia odporności gospodarek przez zmianę struktury finansowania przedsiębiorstw.

Kryzys z 1997 roku nastąpił bezpośrednio po nagłym załamaniu napływu kapitału do azjatyckich gospodarek wschodzących. Zasadniczo napływ kapitału

4 A. Berg, The Asian crisis: Causes, policy response, and outcomes, „IMF Working Paper” 1999, nr 99 (138); A. Szołtun, Systemy bankowe w Azji Poludniowo-Wschodniej, „Materiały i Studia NBP” 2002, z. 114; A. Szczukiewicz, Przebieg i skutki kryzysu azjatyckiego końca XX wieku, [w:] Kryzysy światowe i recesje. Teoria, historia, przykłady, red. K. Piech, Warszawa 2012, s. $481-501$.

5 Ibidem.

6 J.K. Sundaram, Causes of the 1997-1998 East Asian crises and obstacles to implementing lessons, [w:] Lessons from the Asian Financial Crisis, red. R. Carney, New York 2008, s. 33-63. 
do danego kraju może być traktowany jako oznaka rosnącej pozycji, stabilnej kondycji gospodarczej oraz zaufania inwestorów. Kluczowa jest jednak struktura i charakterystyka środków, które napływają. W przypadku krajów azjatyckich finansowanie było niestabilne — krótkoterminowe i w dużym stopniu udzielane w walutach obcych.

Otwarcie na przepływy kapitałowe oraz liberalizacja w przypadku gospodarek wschodzących były postrzegane przed 1997 rokiem jako optymalna strategia rozwojowa. Po kryzysie azjatyckim paradygmat ten został zakwestionowany i zaczęto zwracać szczególną uwagę na cechy napływającego kapitału (termin wymagalności kredytów i pożyczek zaciąganych od nierezydentów i strukturę walutową), a także potrzebę rozwoju krajowej bazy inwestorów ${ }^{7}$. Podobnie znacznej krytyce poddano politykę Międzynarodowego Funduszu Walutowego wobec gospodarek wschodzących, które zostały narażone na szok. Polegała ona na rekomendowaniu restrukturyzacji banków z ograniczonym wsparciem fiskalnym, często w praktyce oznaczającej upadek nierentownych banków, a także na ograniczeniu wydatków rządowych w czasie spowolnienia oraz utrzymywaniu wysokich stóp procentowych ${ }^{8}$.

P. Krugman - jeden z wybitnych badaczy kryzysów finansowych, którego poglądy na kryzys azjatycki oraz ich ewolucja są przedmiotem pogłębionej analizy w punkcie Kryzys nowego typu... — wskazuje, że wschodzące gospodarki azjatyckie były przed 1997 rokiem postrzegane jako atrakcyjny kierunek inwestycyjny, a po 1994 roku (wybuch kryzysu finansowego w Meksyku) stały się głównym celem napływu środków z gospodarek rozwiniętych ${ }^{9}$. Napływ zagranicznego finansowania dłużnego doprowadził do ekspansji kredytowej oraz wspierał w krótkim okresie wzrost gospodarczy. Wraz z niską jakością regulacji w sektorze finansowym przyczynił się jednak do powstania słabych punktów w systemach finansowych Azji Południowo-Wschodniej.

\section{Przyczyny i mechanizm kryzysu z 1997 roku}

W literaturze ${ }^{10}$ wskazuje się trzy główne przyczyny słabości fundamentów wzrostu gospodarczego w Azji przed 1997 okiem:

- rosnący deficyt na rachunku obrotów bieżących, finansowany krótkoterminowymi pożyczkami (dodatkowo często w walutach obcych), który narażał te gospodarki na ryzyko nagłego wycofania się zagranicznych inwestorów;

- liberalizację rynków finansowych, brak odpowiednich regulacji ostrożnościowych, a także niski poziom nadzoru; w konsekwencji azjatyckie banki oraz

${ }^{7}$ M. Weisbrot, Ten years after: The lasting impact of the Asian financial crisis, [w:] Ten Years After: Revisiting the Asian Financial Crisis, red. B. Muchhala, Washington 2007, s. 105-119.

8 J.K. Sundaram, op. cit., s. 33-63.

9 P. Krugman, Powrót recesji, przeł. [z ang.] M. Ruszczyński, Warszawa 2012.

10 Bank Światowy, Asia: The Road to Recovery, Washington 1998. 
przedsiębiorstwa, zadłużając się u inwestorów zagranicznych, otwierały niejednokrotnie niezabezpieczone pozycje walutowe, do czego dodatkowo motywowal je reżim sztywnego kursu walutowego ${ }^{11}$;

- oparcie finansowania przedsiębiorstw wyłącznie na kanale pośrednim (finansowanie bankowe); rynki finansowe — zarówno instrumentów dłużnych, jak i właścicielskich — pozostawały na niskim poziomie rozwoju.

Lata dziewięćdziesiąte XX wieku odznaczały się w przypadku wielu krajów azjatyckich wzrostem gospodarczym, wzrostem popytu wewnętrznego, a także deregulacją, w tym liberalizacją sektora finansowego. W przypadku Tajlandii, Malezji, Indonezji oraz Filipin druga połowa lat osiemdziesiątych oraz lata dziewięćdziesiąte charakteryzowały się istotnym wzrostem gospodarczym opartym w przeważającej mierze na eksporcie oraz wejściem w fazę szybkiego uprzemysłowienia. Ponadto dane makroekonomiczne czterech gospodarek najbardziej dotkniętych kryzysem (Indonezja, Malezja, Korea, Tajlandia, zob. wykresy 1-2) wskazywały w 1996 roku na zdrowe fundamenty. Bezpośrednio przed wybuchem kryzysu gospodarki te charakteryzowały się bezrobociem poniżej 5\% (średniorocznie dla okresu 1990-1995 - poniżej 6\%) oraz nadwyżkami budżetowymi ${ }^{12}$.

Analiza bilansu płatniczego oraz luki między oszczędnościami a inwestycjami w środki trwałe pozwala dostrzec specyficzne cechy rozwoju gospodarek azjatyckich w tym okresie. Deficyty na rachunkach obrotów bieżących, które narastały w latach przedkryzysowych (wykres 3), były finansowane przez napływ finansowania dłużnego z zagranicy. Kraje azjatyckie, w szczególności te, które zostały później najbardziej dotknięte kryzysem (to jest Indonezja, Korea Południowa, Malezja, Filipiny, Tajlandia), prowadziły bezpośrednio przed 1997 rokiem politykę zmierzającą do przyciągania kapitałów zagranicznych. Utrzymywały sztywne względem USD kursy walutowe. Napływowi kapitału na rynki wschodzące sprzyjał także w pierwszej połowie lat dziewięćdziesiątych malejący trend jeśli chodzi o stopy procentowe $\mathrm{w}$ gospodarkach rozwiniętych ${ }^{13}$.

Wykres 3 ilustruje także istotną zmianę polityki handlowej w analizowanych gospodarkach. Po kryzysie z 1997 roku kraje te poza epizodycznymi wyjątkami prowadziły politykę nadwyżki na rachunku obrotów bieżących. Jedynie w Indonezji od 2012 roku ponownie utrzymuje się umiarkowany deficyt na rachunku obrotów bieżących.

Rozmiar luki między oszczędnościami krajowymi a nakładami (inwestycjami) na środki trwałe w latach dziewięćdziesiątych (wykres 4) różnił się między gospodarkami azjatyckimi. Wśród pięciu gospodarek najbardziej dotkniętych kryzysem azjatyckim z 1997 roku (Indonezja, Korea Południowa, Malezja, Filipiny, Tajlandia) wszystkie poza Indonezją charakteryzowały się od końca lat osiemdziesiątych

\footnotetext{
11 J. K. Sundaram, op. cit.

12 Ibidem.

13 A. Szołtun, op. cit.
} 


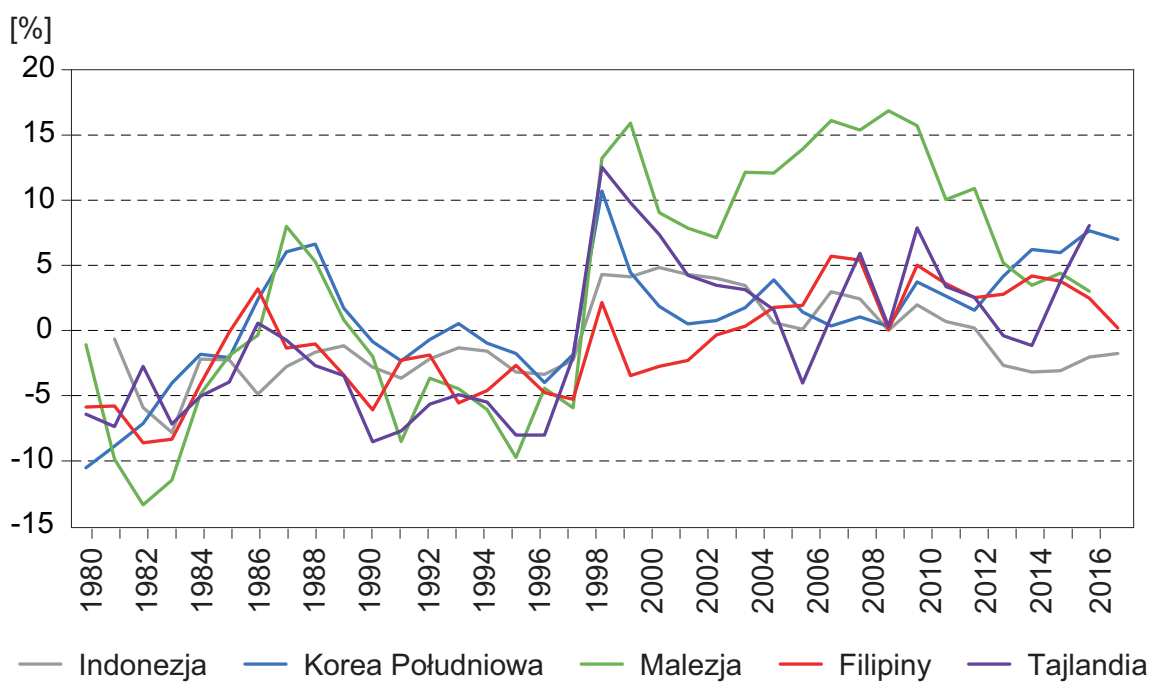

Wykres 3. Bilans na rachunku obrotów bieżących w wybranych krajach azjatyckich jako procent PKB

Źródło: Bank Światowy.

[\%]

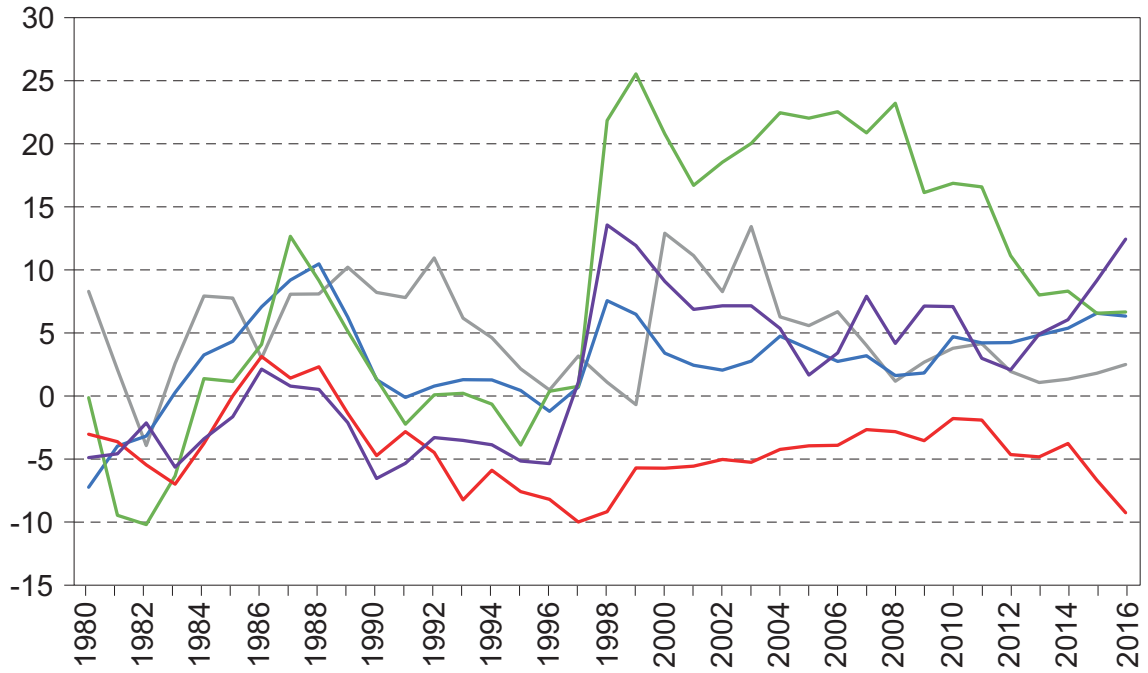

- Indonezja — Korea Południowa - Malezja — Filipiny — Tajlandia

Wykres 4. Luka między oszczędnościami krajowymi a inwestycjami w środki trwałe jako procent PKB

Źródło: Bank Światowy. 
do 1997 roku poziomem oszczędności krajowych niewystarczającym do sfinansowania rosnących potrzeb inwestycyjnych. Luka inwestycyjna dla Korei Południowej oraz Malezji była nieznaczna i oscylowała wokół 0\% PKB. W przypadku Tajlandii i Filipin była jednak istotnie większa - sięgała nawet ponad 5\% PKB.

Napływający kapitał nie zawsze był inwestowany efektywnie. Na przykład na rynku nieruchomości przed kryzysem pojawiła się bańka inwestycyjna. Inwestowanie w nieruchomości w latach dziewięćdziesiątych w Azji stało się dodatkowo przyczyną negatywnego zjawiska dotyczącego stabilności bilansów przedsiębiorstw. Czynsze w tym czasie były przeważnie w gospodarkach azjatyckich rozliczane w walutach krajowych. Inwestycja w nieruchomości generowała zatem problem niedopasowania walutowego. W ogólności część finansowania w walutach obcych od nierezydentów była lokowana w produkcję dóbr niehandlowych (w sensie wymiany międzynarodowej), która to przynosiła przychody w walutach krajowych $^{14}$.

Istotnym czynnikiem wzmacniającym napływ zagranicznego finansowania dłużnego do krajów azjatyckich była polityka sztywnego kursu walutowego wobec USD. Niestety sprzyjała ona również pojawieniu się oczekiwań co do braku wahań kursowych i w rezultacie przyczyniła się do relatywnie niewielkiego poziomu zabezpieczenia przed ryzykiem walutowym w przedsiębiorstwach azjatyckich ${ }^{15}$.

Polityka sztywnego kursu walutowego pośrednio przyczyniła się także do wzrostu rezerw $w$ walutach zagranicznych oraz zwiększenia podaży waluty krajowej. Przykładowa instytucja finansowa z państwa azjatyckiego $X$, która pożyczała środki w walucie obcej od nierezydenta, musiała później kupić walutę krajową $X$, aby udzielić kredytu przedsiębiorcy-rezydentowi. Pojawiał się zatem systematyczny popyt na walutę krajową $X$. Bank centralny $X$, aby utrzymać kurs walutowy na niezmienionym poziomie, musiał $\mathrm{w}$ tej sytuacji sprzedawać walutę krajową. Rosła zatem podaż pieniądza krajowego i rezerwy banku centralnego. Pobudzony $\mathrm{w}$ ten sposób mnożnik kreacji pieniądza powodował wzrost kredytu ${ }^{16}$, a także przyczyniał się do napędzenia bańki na rynku nieruchomości ${ }^{17}$.

P. Krugman zwraca uwagę, że kraje azjatyckie starały się prowadzić operacje sterylizujące po interwencjach walutowych. Okazały się one jednak nieskuteczne. Bank centralny emitował instrumenty dłużne i starał się w ten sposób ściągnąć z rynku środki finansowe w walucie krajowej. Musiał jednak zaoferować atrakcyjne oprocentowanie, aby znaleźć nabywców na te instrumenty. W konsekwencji prowadziło to do wzrostu krajowego poziomu stopy procentowej, wzrostu różnicy

14 J.K. Sundaram, op. cit.

15 Ibidem

16 P. Krugman, op. cit.; P. Alba et al., Volatility and Contagion in a Financially-Integrated World: Lessons from East Asia's Recent Experience, PAFTAD 24 Conference Asia Pacific Financial Liberalization and Reform, Chiang Mai 1998.

17 J.K. Sundaram, op. cit. 
stóp procentowych między gospodarką krajową a gospodarkami rozwiniętymi. Szukanie dłużnego finansowania zagranicznego przez rezydentów gospodarek azjatyckich stawało się zatem jeszcze bardziej atrakcyjne ${ }^{18}$.

Zgodnie z koncepcją trójkąta niemożliwości polityki gospodarczej (impossible trinity) ${ }^{19} \mathrm{w}$ polityce danego kraju musi dokonać się wybór dwóch spośród następujących trzech elementów: sztywny kurs walutowy, otwartość gospodarki na przepływy kapitałowe oraz niezależna polityka pieniężna. Model rozwoju gospodarek azjatyckich z lat dziewięćdziesiątych XX wieku oznaczał zatem, że zrezygnowały one $\mathrm{z}$ aktywnego wykorzystania polityki pieniężnej do łagodzenia szoków. Ostatecznie wzrost inwestycji oraz — następnie — wzrost zamożności gospodarstw domowych doprowadziły do istotnego wzrostu importu i w konsekwencji — do deficytów handlowych. P. Krugman obrazowo stwierdza, że w przypadku gospodarek azjatyckich przed kryzysem w 1997 roku kredyty zaciągnięte w walucie obcej ,zamiast zasilać lokalny rynek, zostały wykorzystane do spłaty kosztów importu"20.

Wzrost całkowitego zadłużenia zewnętrznego cechował w latach dziewięćdziesiątych wszystkie azjatyckie gospodarki rozwijające się i wschodzące ${ }^{21}$ na poziomie zagregowanym (wykres 5). Niedoskonałość modelu rozwoju wschodzących gospodarek azjatyckich przed 1997 rokiem sprowadzała się nie tyle do samego deficytu na rachunku obrotów bieżących (wykres 3) czy luki między oszczędnościami krajowymi a inwestycjami (wykres 4), ile do sposobu sfinansowania niedoborów. Wykres 6 przedstawia zagregowane przepływy kapitałowe netto (w mld USD) dla pięciu gospodarek ${ }^{22}$ azjatyckich najbardziej dotkniętych późniejszym kryzysem z 1997 roku.

Wzrost całkowitego napływu prywatnego kapitału netto od końca lat osiemdziesiątych był w przeważającej mierze spowodowany wzrostem inwestycji portfelowych oraz wzrostem finansowania dłużnego. Napływ bezpośrednich prywatnych inwestycji zagranicznych odgrywał mniejszą rolę, a to one mogą być utożsamiane z kapitałem długoterminowym niepodatnym na bieżący sentyment rynkowy. Dekompozycja przepływów kapitałowych ukazana na wykresie 6 zdaje się zresztą potwierdzać obecną w literaturze ${ }^{23}$ tezę o względnej stałości przepły-

18 P. Krugman, op. cit.

19 R.A. Mundell, Capital mobility and stabilization policy under fixed and flexible exchange rates, „The Canadian Journal of Economics and Political Science” 29, 1963, nr 4, s. 475-485; M. Obstfeld, J.C. Shambaugh, A.M. Taylor, The Trilemma in History: Tradeoffs among Exchange Rates, Monetary Policies, and Capital Mobility, Dublin 2004.

20 P. Krugman, op. cit., s. 78.

${ }^{21}$ Klasyfikacja według MFW (Emerging and Developing Asia): Bangladesz, Bhutan, Brunei, Darussalam, Kambodża, Chiny, Fidżi, Indie, Indonezja, Kiribati, Laos, Malezja, Malediwy, Wyspy Marshalla, Mikronezja, Mongolia, Mianma, Nauru, Nepal, Palau, Papua Nowa Gwinea, Filipiny, Samoa, Wyspy Salomona, Sri Lanka, Tajlandia, Timor Wschodni, Tonga, Tuvalu, Vanatu, Wietnam.

22 Indonezja, Korea Południowa, Malezja, Filipiny, Tajlandia.

23 C.-Y. Chang, Capital Flows, Financial Markets and Banking Crises, London 2017. 


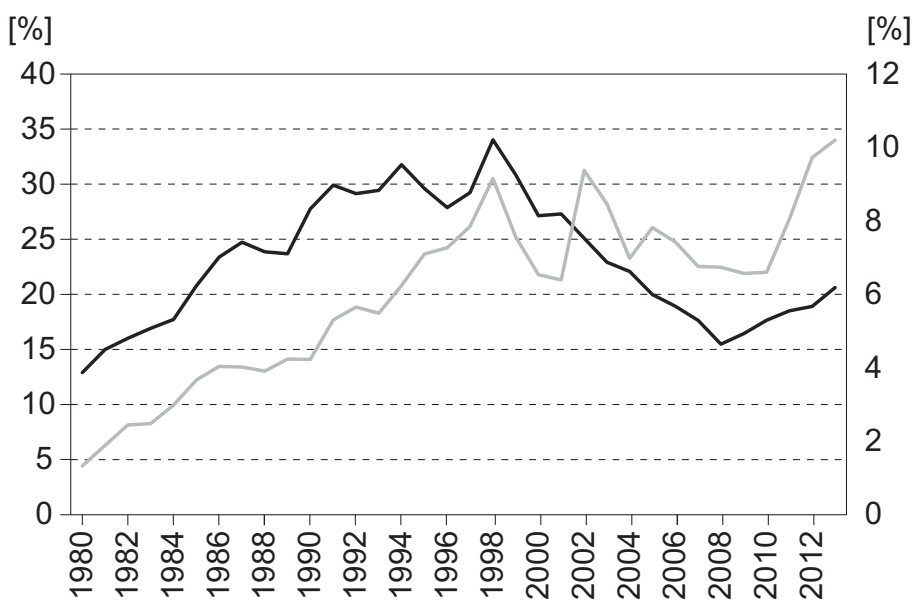

— Całkowity dług zewnętrzny (\% PKB; lewa oś)

Koszt obsługi długu zewnętrznego (\% PKB; prawa oś)

Wykres 5. Całkowity dług zewnętrzny oraz całkowity koszt obsługi długu zewnętrznego jako procent PKB dla rozwijających się i wschodzących gospodarek azjatyckich

Źródło: MFW.

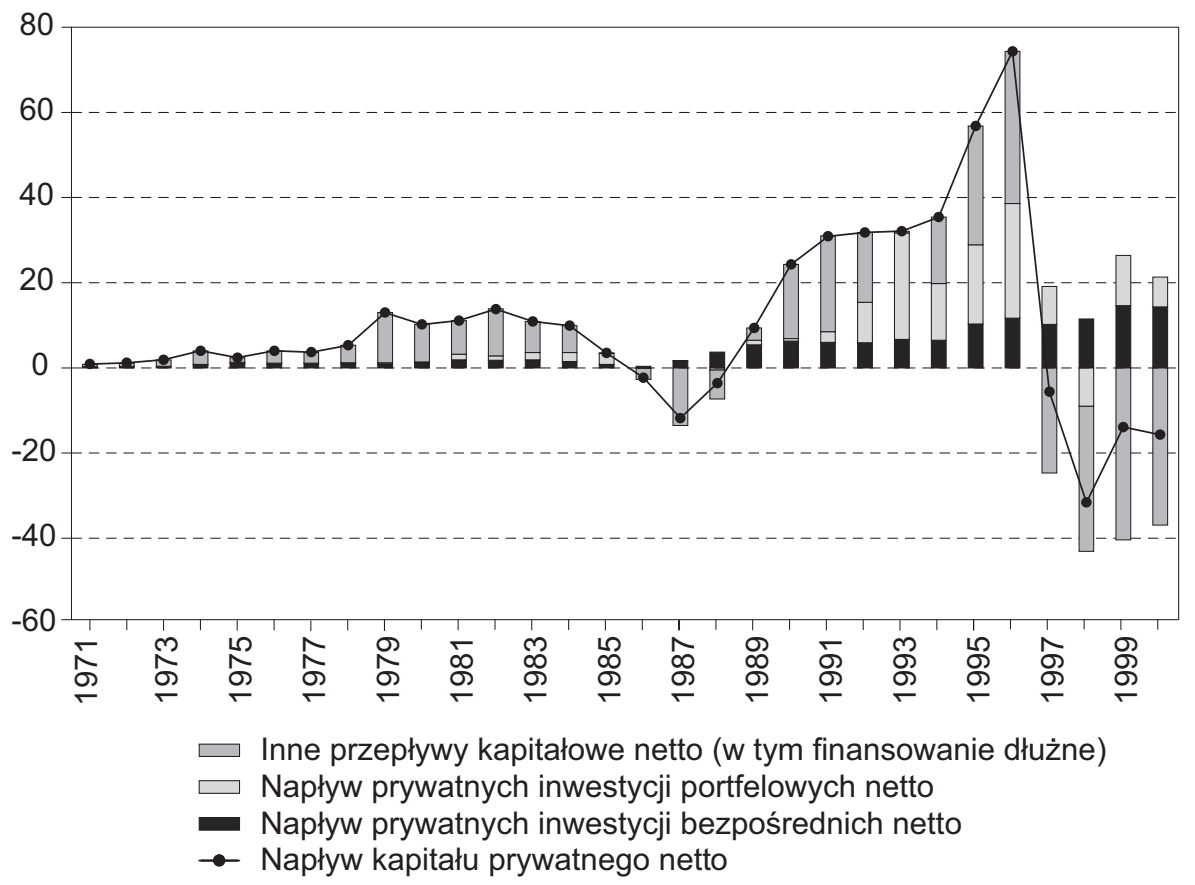

Wykres 6. Przepływy kapitałowe netto przed 2000 rokiem w mld USD — wartości zagregowane dla pięciu krajów najbardziej dotkniętych kryzysem azjatyckim z 1997 roku (Indonezja, Korea Południowa, Malezja, Filipiny, Tajlandia)

Źródło: MFW.

Studenckie Prace Prawnicze, Administratywistyczne

i Ekonomiczne 33, 2020

(C) for this edition by CNS 
wów kapitałowych w formie bezpośrednich inwestycji zagranicznych w porównaniu do inwestycji portfelowych. Po 1997 roku odpływ kapitału prywatnego był spowodowany ucieczką finansowania dłużnego. Inwestycje bezpośrednie (czyli projekty długoterminowe budowane etapami oraz przynajmniej teoretycznie poparte analizą fundamentalną opłacalności inwestycji) nie podlegały znacznym wahaniom.

Struktura napływu kapitału zagranicznego do wschodzących gospodarek azjatyckich stanowiła zatem o słabości ich systemów finansowych oraz podatności na szoki. Po pierwsze, należy odnotować sam fakt finansowania potrzeb rozwijających się gospodarek długiem zagranicznym. Po drugie, charakterystyka długu z perspektywy stabilności systemu finansowego była niekorzystna przyczyniała się do narastania ryzyka systemowego ${ }^{24}$. Kraje azjatyckie zadłużały się w walutach obcych. Rósł ponadto udział długu krótkoterminowego. Analiza wykresów 7 i 8 pozwala stwierdzić, że wzrost przepływów finansowych netto z tytułu transakcji dłużnych z zagranicą w wartościach bezwzględnych (mld USD) rósł w Indonezji, Malezji, Filipinach oraz Tajlandii głównie za sprawą wzrostu zadłużenia krótkoterminowego (o zapadalności nieprzekraczającej roku). Zmiany udziału zadłużenia krótkoterminowego w całkowitym zadłużeniu zewnętrznym wskazanych krajów zostały zaprezentowane na wykresie 10. Od końca lat osiemdziesiątych do wybuchu kryzysu azjatyckiego wskaźnik ten rósł we wszystkich analizowanych państwach, osiągając poziom około 30\% w Malezji i około 40\% w Tajlandii w 1996 roku.

Problemem wschodzących gospodarek azjatyckich w latach dziewięćdziesiątych XX wieku było zadłużenie prywatne. Zostało to ukazane na przykładzie ścieżek wzrostu przepływów finansowych netto z tytułu długu sektora prywatnego bez gwarancji rządowych dla wybranych krajów na wykresie 9. P. Krugman dodaje jednak, że przedsiębiorstwa z gospodarek azjatyckich były niejednokrotnie integralnie powiązane z rządem, co rodziło problem pokusy nadużycia nazywanego również bardziej obrazowo „kapitalizmem kolesiów”25.

Zadłużanie się sektora prywatnego miało różny charakter w zależności od kraju. Kapitał zagraniczny napływał do Azji pośrednio przez finansowanie akcji kredytowej krajowych banków lub też bezpośrednio, to jest przez pożyczki i kredyty zaciągane przez duże azjatyckie przedsiębiorstwa na rynkach międzynarodowych.

W literaturze przedmiotu zwraca się uwagę, że przykładowo na koniec czerwca 1997 roku portfel należności od podmiotów indonezyjskich w aktywach banków

${ }^{24}$ Ryzyko systemowe jest tu rozumiane zgodnie z późniejszą definicją wypracowaną po globalnym kryzysie finansowym z 2008 roku: jako ryzyko zakłócenia w funkcjonowaniu systemu finansowego, które w razie materializacji zaburza działanie systemu finansowego i gospodarki narodowej jako całości. Zob. art. 4 ust. 15 ustawy z dnia 5 sierpnia 2015 roku o nadzorze makroostrożnościowym nad systemem finansowym i zarządzaniu kryzysowym w systemie finansowym (Dz.U. z 2015 r. poz. 1513).

25 P. Krugman, op. cit., s. 78. 


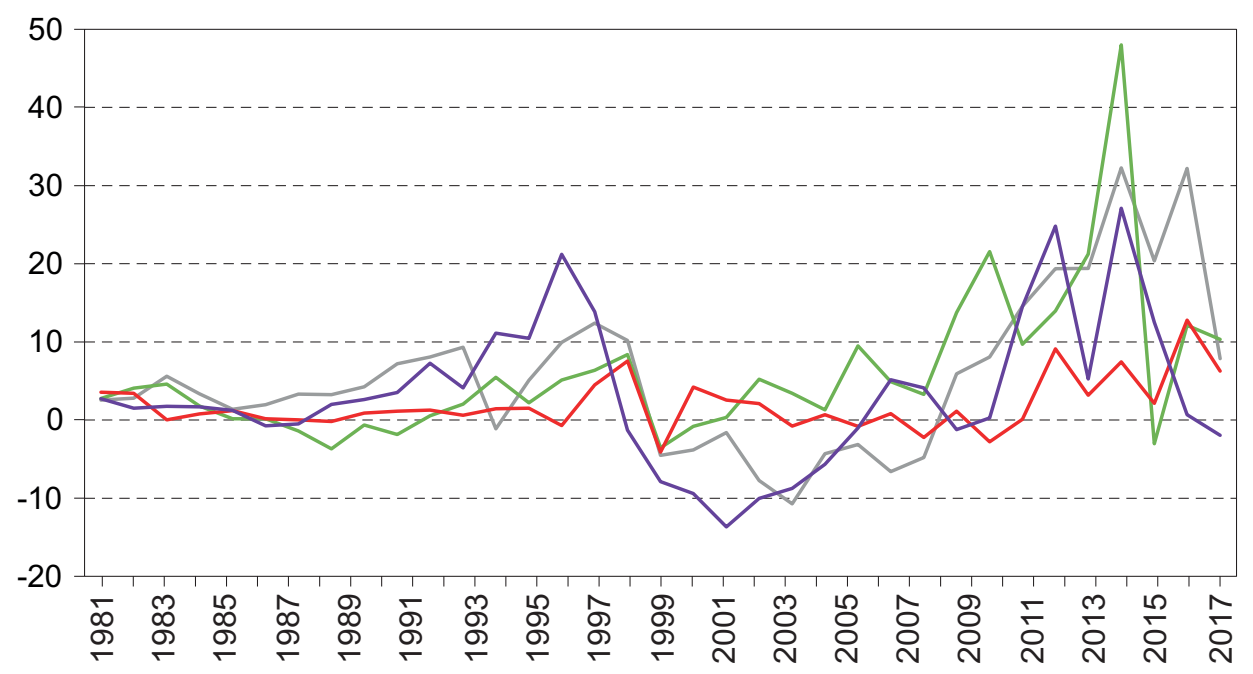

Wykres 7. Przepływy finansowe netto z tytułu transakcji dłużnych z zagranicą w mld USD w wybranych krajach azjatyckich

Źródło: Bank Światowy.

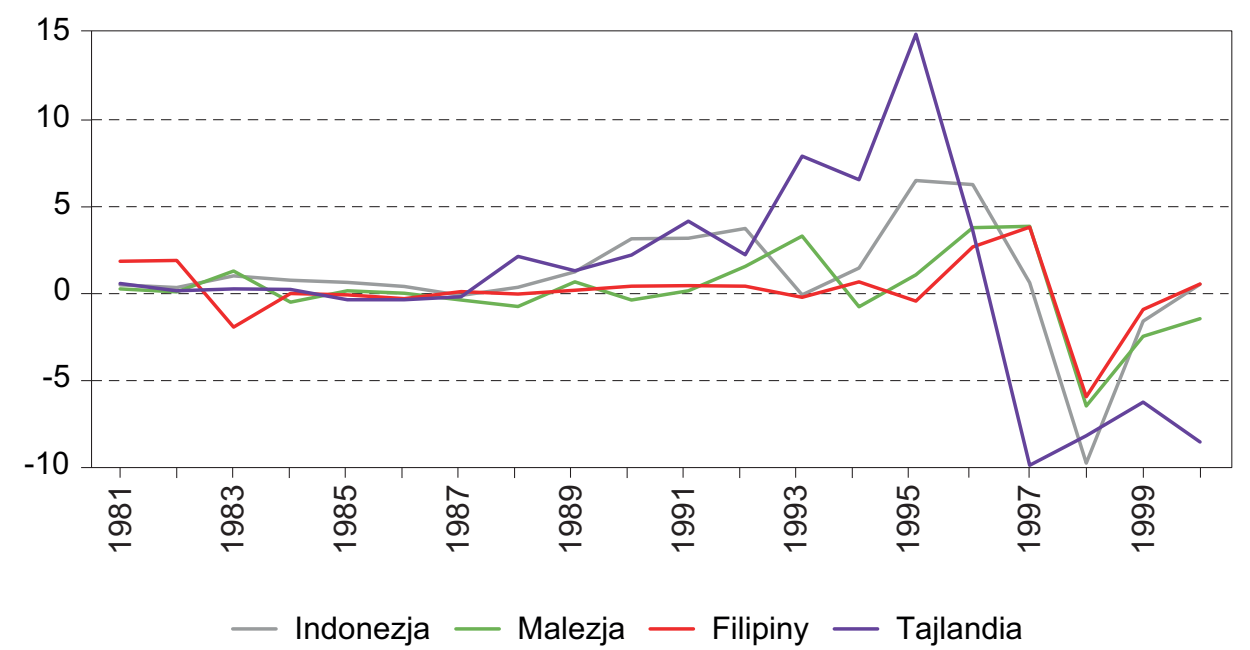

Wykres 8. Przepływy finansowe netto z tytułu krótkoterminowych transakcji dłużnych z zagranicą w mld USD w wybranych krajach azjatyckich

Źródło: Bank Światowy. 


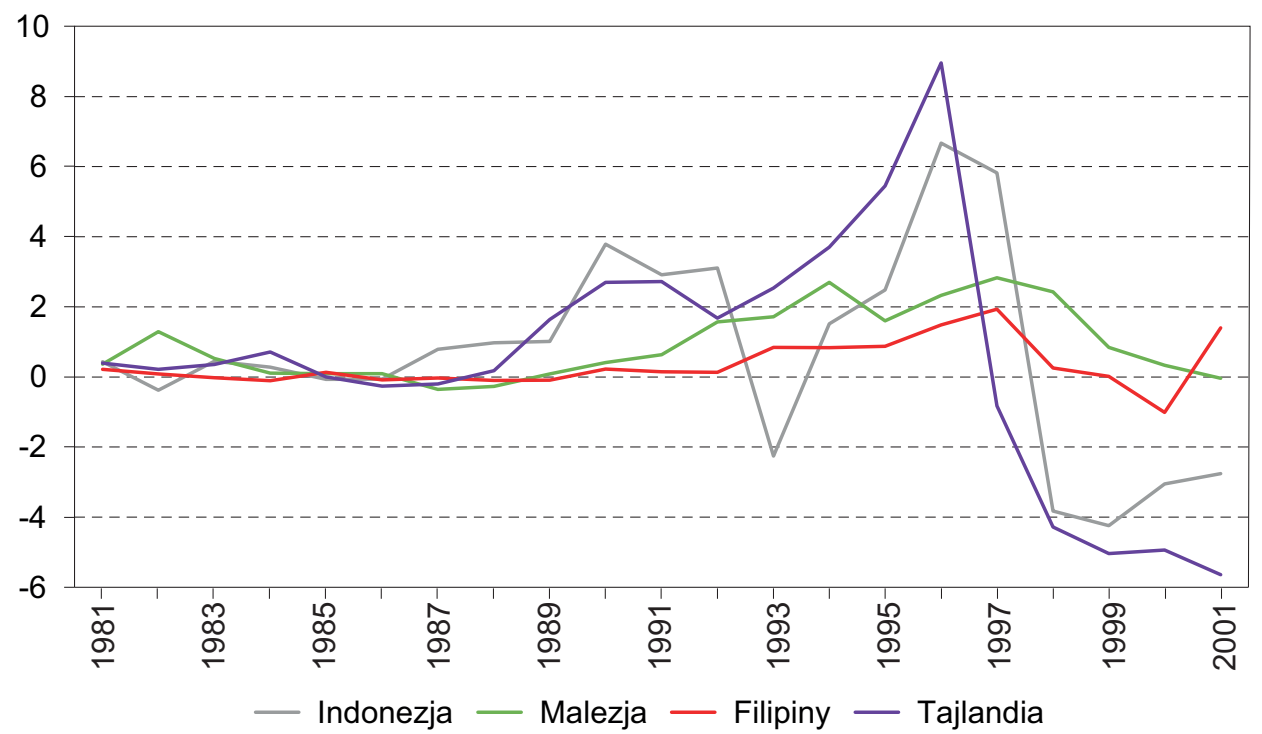

Wykres 9. Przepływy finansowe netto z tytułu zagranicznego długu sektora prywatnego bez gwarancji rządowych w mld USD dla wybranych krajów azjatyckich

Źródło: Bank Światowy.

$[\%]$

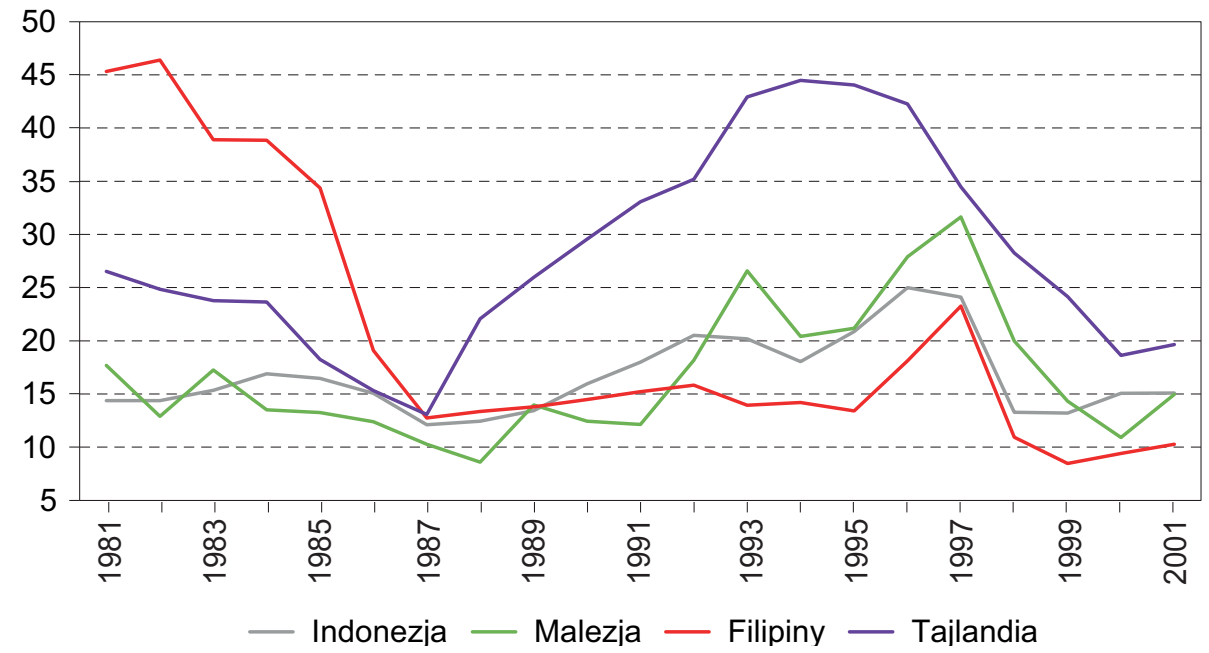

Wykres 10. Udział długu krótkoterminowego (do 1 roku) w całkowitym zadłużeniu zewnętrznym w wybranych krajach azjatyckich (w \%)

Źródło: Bank Światowy. 
komercyjnych z gospodarek rozwiniętych raportujących do Banku Rozrachunków Międzynarodowych składał się w 67,7\% z ekspozycji wobec prywatnych niebankowych przedsiębiorst $w^{26}$. Przewagę bezpośrednich ekspozycji kredytowych banków zagranicznych (bez udziału azjatyckich banków rezydentów) na przedsiębiorstwa z gospodarek wschodzących możemy zaobserwować również w przypadku Malezji i Tajlandii. W przeciwieństwie do wymienionych krajów Korea Południowa odznaczała się przewagą finansowania dłużnego pozyskanego za pośrednictwem koreańskich banków-rezydentów. Ekspozycje takie stanowiły 65,1\% portfela należności w bilansach banków komercyjnych z krajów rozwiniętych od podmiotów z Korei Południowej.

Różnice dotyczące kanału napływu finansowania bankowego do Azji Południowo-Wschodniej wynikały niejednokrotnie z przyczyn regulacyjnych. W Indonezji na przykład przedsiębiorstwa zadłużały się bezpośrednio w zagranicznych bankach ze względu na to, że sektor realny nie podlegał (w przeciwieństwie do banków indonezyjskich) ograniczeniom co do liczby posiadanych dewiz. W Korei Południowej natomiast funkcjonował w tym czasie schemat regulacyjny umożliwiający czebolom (największym koreańskim konglomeratom) posiadanie zarówno przedsiębiorstw sektora realnego, jak i banków, które kredytowały powiązane przedsiębiorstwa $^{27}$.

Cechą charakterystyczną finansowania kredytowego z banków zagranicznych, napływającego do Azji Południowo-Wschodniej przed 1997 rokiem pozostawało jednak - bez względu na zaangażowanie azjatyckich banków rezydentów czy też jego brak — podwójne niedopasowanie (double mismatch dillema). Dług charakteryzował się krótkimi terminami wymagalności oraz tym, że został pozyskany w walutach obcych. Udział długu krótkoterminowego w długu zewnętrznym ogółem dla wybranych krajów został zaprezentowany na wykresie 10, a rosnący w latach dziewięćdziesiątych koszt obsługi tego długu — na wykresie 11.

W literaturze ${ }^{28}$ suboptymalną strukturę zadłużenia sektora przedsiębiorstw krajów azjatyckich wiąże się z niekompletnością rynku finansowego. Autorzy wymienionych już pozycji posługują się metaforą grzechu pierworodnego (original sin). Rozumieją pod tym pojęciem sytuację, kiedy podmioty rynkowe w gospodarce wschodzącej nie są w stanie — ze względu na uwarunkowania rynkowe lub instytucjonalne - pożyczać środków finansowych w walucie krajowej za granicą, jak również zaciągać długu o odpowiednio długiej wymagalności (również jeśli chodzi o pożyczki od rezydentów).

26 J.K. Sundaram, op. cit.

27 A. Szołtun, op. cit.

28 B. Eichengreen, R. Hausmann, U. Panizza, Currency mismatches, debt intolerance, and original sin why they are not the same and why it matters?, [w:] Capital Controls and Capital Flows in Emerging Economies: Policies, Practices and Consequences, red. S. Edwards, Chicago 2004, s. 121-169. 


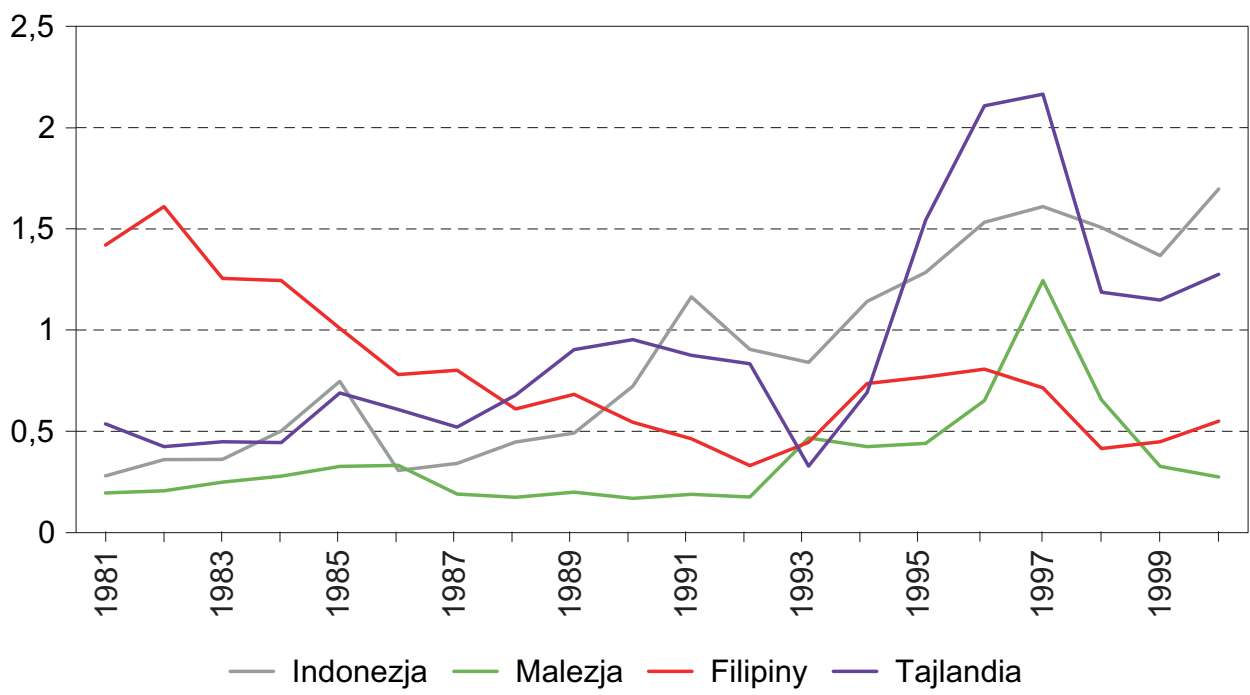

Wykres 11. Koszty obsługi zewnętrznego długu krótkoterminowego (innego niż długoterminowy) w wybranych krajach azjatyckich (w mld USD) przed kryzysem 1997 roku

Źródło: Bank Światowy.

[\%]

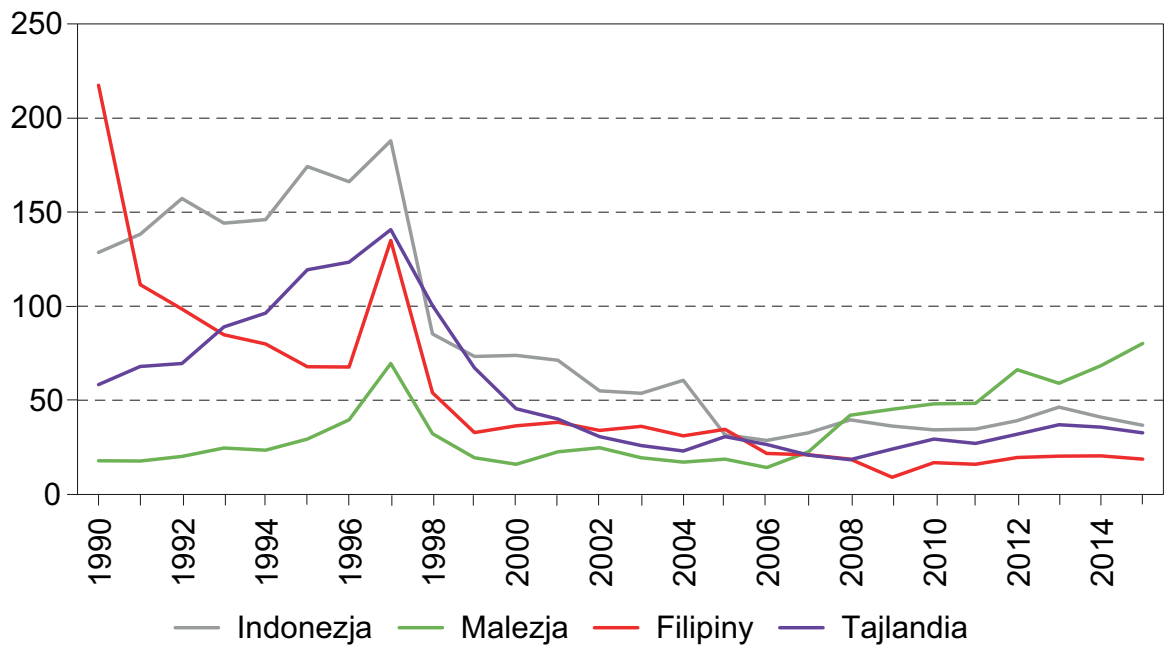

Wykres 12. Dług krótkoterminowy (do 1 roku) jako procent rezerw banku centralnego dla wybranych krajów azjatyckich

Źródło: Bank Światowy. 
W takich warunkach dług podmiotów w gospodarce wschodzącej będzie odznaczał się niedopasowaniem bilansowym ${ }^{29}$. Ponadto $\mathrm{w}$ takiej sytuacji można oczekiwać, że finansowanie zagraniczne w walucie obcej będzie tańsze ze względu na przeciętnie niższy poziom stóp procentowych w krajach rozwiniętych (krajach pożyczkodawców) w porównaniu z gospodarkami wschodzącymi (kraje pożyczkobiorców). Powstaje zatem bodziec do zadłużania się za granicą w transakcjach o krótkim terminie wymagalności i rolowania długu przez podmioty z gospodarek wschodzących. Podmioty te stają się zatem wrażliwe zarówno na wzrost stóp procentowych w krajach rozwiniętych (wzrost kosztu odnowienia transakcji dłużnej), jak i na zmiany kursu walut — double mismatch dilemma.

W przypadku omawianych gospodarek azjatyckich dodatkowo jako nieadekwatna motywacja (bad incentive) zadziałał reżim sztywnych kursów walutowych. Przedsiębiorstwa - rezydenci gospodarek azjatyckich generujące przychody w walutach krajowych — nie oczekiwały zmiany kursu walutowego. W konsekwencji nie doszacowały ryzyka z tym związanego i często nie zdecydowały się na zawarcie transakcji zabezpieczających takie pożyczki na rynku pochodnym ${ }^{30}$. Banki, a także przedsiębiorstwa sektora realnego w krajach azjatyckich w latach dziewięćdziesiątych ponosiły zwiększone podwójne ryzyko dotyczące terminów wymagalności zaciągniętych kredytów (de facto ryzyko płynnościowe) oraz ryzyko wahań kursowych. W kryzysowym 1997 roku wskazane źródła ryzyka zmaterializowały się.

Nieograniczona międzynarodowa mobilność kapitału może doprowadzić do tego, że kraj utraci źródła finansowania dłużnego z przyczyn niezależnych od własnej gospodarki ${ }^{31}$. Dotyczy to w szczególności gospodarek wschodzących i wynika między innymi z praktyki biznesowej dużych inwestorów instytucjonalnych. W ramach dywersyfikacji portfela inwestycyjnego wewnętrzne limity ekspozycji inwestorów (zależne od ratingu poszczególnych krajów) dotyczą grup (koszyków) gospodarek. Dlatego też negatywna zmiana postrzegania gospodarek wschodzących może wpływać na podejście inwestorów również do tych krajów z grupy, które same nie doświadczyły szoku ${ }^{32}$.

Sposobem na zabezpieczenie gospodarki przed nagłą deprecjacją waluty wynikającą z odpływu kapitału są interwencje walutowe banku centralnego. Utrzymywanie odpowiednio wysokich rezerw jest zatem w literaturze nazywane ,pierwszą

29 Ibidem.

30 J.K. Sundaram, op. cit.

31 A. Sławiński, M. Dusza, Kryzysy walutowe w krajach otwierajacych się na wymiane, „Materiały i Studia NBP” 1998, z. 70.

32 P. Krugman, Will Asia Bounce Back?, speech for Credit Suisse First Boston, Hongkong, 1998, http://web.mit.edu/krugman/www/suisse.html (dostęp: 15.01.2020); S. Radelet, J. Sachs, The onset of the East Asian financial crisis, [w:] Currency Crises, red. P. Krugman, Cambridge, MA 2000 . 
linią obrony" stabilności gospodarki danego kraju ${ }^{33}$. Wymienieni autorzy wskazują, że „drugą linią obrony” jest dobra sytuacja fiskalna, w szczególności nadwyżka budżetowa, która po pierwsze zwiększa udział oszczędności krajowych w dochodzie narodowym, a po drugie otwiera możliwość wsparcia finansowego banków zagrożonych upadłością w przypadku kryzysu walutowego i w konsekwencji kryzysu płynnościowego w sektorze bankowym. Podczas kryzysu azjatyckiego „pierwsza linia obrony” była stanowczo zbyt słaba. Wybór schematu polityki gospodarczej (otwartość na przepływy kapitałowe oraz sztywny kurs walutowy) okazał się nie do utrzymania wobec szoku związanego z odpływem finansowania. „Druga linia obrony” nie została wykorzystana, gdyż w początkowej fazie kryzysu — zgodnie z zaleceniami MFW — rządy krajów azjatyckich dotkniętych kryzysem nie zdecydowały się na stymulację fiskalną.

Wykres 12 ukazuje wartość zewnętrznego długu krótkoterminowego wyrażoną jako procent rezerw banku centralnego dla wybranych krajów azjatyckich. Wskaźnik ten może być interpretowany jako miara odporności danej gospodarki na szok związany z odpływem finansowania zagranicznego. Przed kryzysem w 1997 roku tak rozumiana odporność spadała w Indonezji, Malezji, Filipinach i Tajlandii (wraz ze wzrostem wskaźnika na wykresie 12).

W literaturze ${ }^{34}$ wskazuje się przykład Filipin jako kraju, w którym relatywnie niski poziom rezerw walutowych spowodował spekulację na deprecjację waluty krajowej. Zagraniczni inwestorzy, zakładając, że bank centralny nie będzie w stanie obronić kursu waluty krajowej, podjęli decyzję o zaangażowaniu spekulacyjnym. Przez kolejne dwie dekady po 1997 roku stosunek zadłużenia krótkoterminowego do rezerw banku centralnego w Indonezji, Malezji, Filipinach i Tajlandii utrzymywał się poniżej 100\%.

Zaczerpnięty z literatury ${ }^{35}$ schemat 1 obrazuje (na dużym poziomie ogólności) mechanizm narastania słabych punktów w fazie wzrostowej cyklu finansowego w krajach azjatyckich przed 1997 rokiem. Wśród głównych źródeł ryzyka dla krajów azjatyckich przed 1997 rokiem należy wskazać kwestię cykliczną (nadmierny wzrost krajowej akcji kredytowej), a także strukturę długu — istotny udział krótkoterminowego finansowania w walutach obcych.

Na schemacie 1 zaznaczono również, że napływ kapitałów doprowadził w Azji Południowo-Wschodniej do nadpłynności w sektorze bankowym, a w konsekwencji przyczyniał się do zwiększania krajowej akcji kredytowej oraz konsumpcji. W ten sposób następowała stymulacja wzrostu gospodarczego. Schemat 1 ukazuje także narastanie bańki inwestycyjnej na rynku nieruchomości napędzanej wzrostem cen aktywów.

\footnotetext{
33 A. Sławiński, M. Dusza, op. cit.

34 Ibidem.

35 P. Alba et al., op. cit., s. 34.
} 


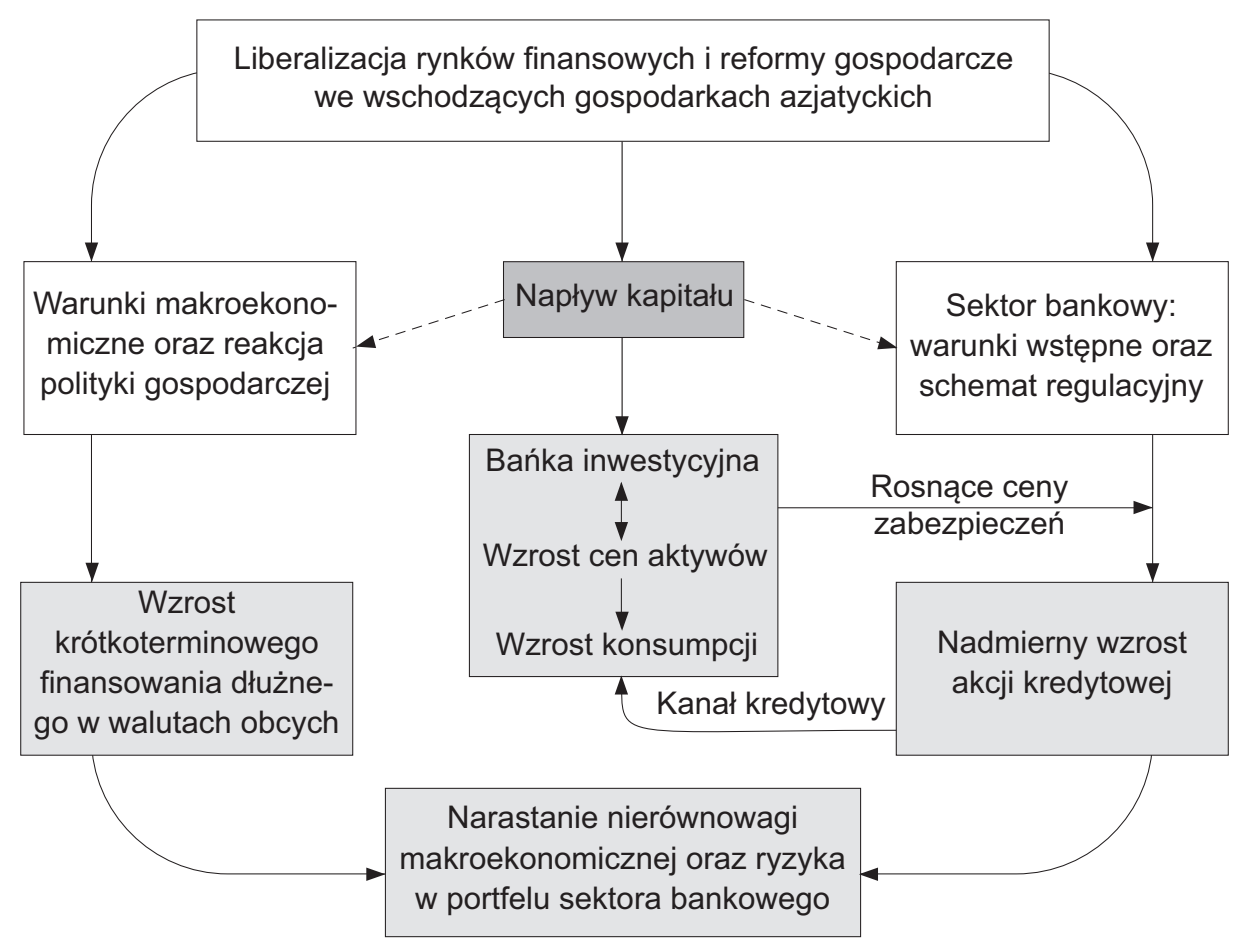

Schemat 1 . Narastanie słabych punktów w systemach finansowych krajów azjatyckich przed kryzysem z 1997 roku

Źródło: P. Alba et al., op. cit, s. 34.

Tak długo, jak USD był w trendzie deprecjacyjnym, sztywne kursy walutowe wspierały tempo eksportu gospodarek wschodnioazjatyckich (wykres 13). Od 1995 roku sztywne kursy walutowe wraz z rosnącą inflacją w krajach azjatyckich oraz aprecjacją USD doprowadziły do spadku konkurencyjności gospodarek azjatyckich i spadku tempa wzrostu eksportu ${ }^{36}$.

Wzrost akcji kredytowej w latach dziewięćdziesiątych wiązał się z pogorszeniem jakości portfela kredytowego. Słabości instytucjonalne, to jest powiązania między bankami a kredy towanymi przedsiębiorstwami, oraz niedoskonały nadzór bankowy doprowadziły do wzrostu liczby kredytów udzielanych bez należytej oceny zdolności kredytowej. W konsekwencji już w połowie 1998 roku znacznie wzrósł odsetek kredytów zagrożonych (opóźnionych w spłacie) — na przykład w Indonezji wskaźnik ten wyniósł wtedy 75\%, a w Tajlandii 50\% ${ }^{37}$.

36 A. Sławiński, M. Dusza, op. cit.; A. Szołtun, op. cit.

37 Ibidem. 


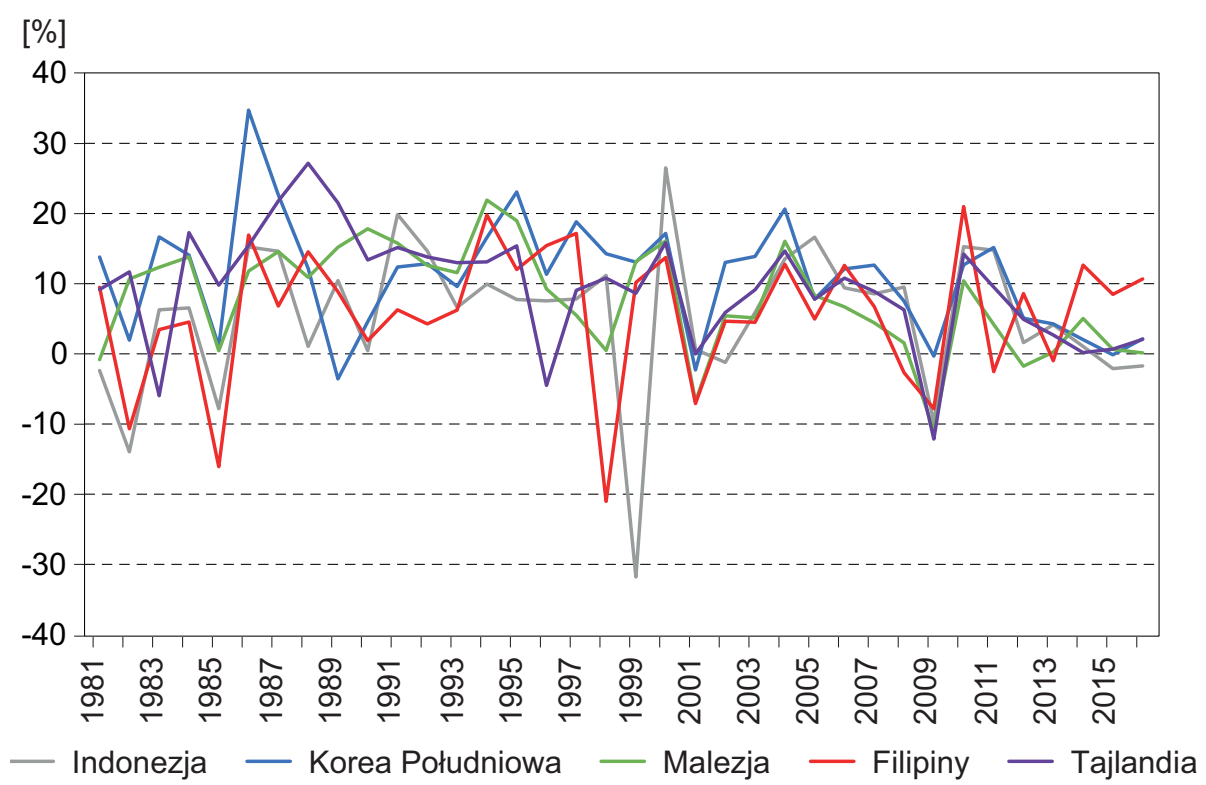

Wykres 13. Roczne tempo wzrostu eksportu dóbr i usług dla wybranych krajów azjatyckich Źródło: Bank Światowy.

W 1997 roku inwestorzy zaczęli wycofywać środki z inwestycji w Azji Południowo-Wschodniej. W przypadku finansowania dłużnego oznaczało to nieprzyznanie kolejnego kredytu (zrolowanie długu). Władze krajów wschodnioazjatyckich próbowały utrzymywać kursy walut przez interwencje walutowe. Po wykorzystaniu niemal całych rezerw banku centralnego Tajlandia - pierwszy kraj dotknięty przez kryzys azjatycki — została zmuszona do uwolnienia kursu waluty krajowej (bahta). Po tej decyzji nastąpiła deprecjacja waluty tajlandzkiej (o 20\%). Następnie spadku wartości waluty doświadczyły: Indonezja, Filipiny, Malezja, Singapur. Efekt zarażania miał swoje źródło nie tylko w powiązaniach między gospodarkami wschodnioazjatyckimi (wzajemne inwestycje portfelowe, inwestycje bezpośrednie oraz ekspozycje dłużne), ale przede wszystkim w sposobie postrzegania regionu przez inwestorów z gospodarek rozwiniętych. Wycofywali oni środki ze wszystkich krajów regionu (jako składowych koszyka inwestycyjnego) bez analizy sytuacji pojedynczych gospodarek ${ }^{38}$. Na skutki kryzysu dla azjatyckich gospodarek wschodzących wpływ miała także spóźniona i nieadekwatna reakcja polityki gospodarczej. Zacieśnienie polityki pieniężnej i fiskalnej, począwszy od 1997 roku, przyniosło skutki przeciwne do zamierzonych. Wyższe stopy procentowe miały powstrzymać lub zmniejszyć skalę odpływu kapitału. Przypadły one jednak na okres spadku eksportu oraz spowolnienia gospodarczego.

38 P. Krugman, Will Asia ...; S. Radelet, J. Sachs, op. cit. 
Kryzysem w 1997 roku została dotknięta także Japonia. Istotnym problemem sektora bankowego w tym kraju była duża ekspozycja (podobnie jak na przykład w Tajlandii) na sektor nieruchomości. Niskiej jakości regulacje i nieefektywny nadzór bankowy otworzyły możliwość wzrostu portfela kredytów na nieruchomości przyznanych bez uprzedniej odpowiednio dokładnej analizy ryzyka kredytowego ${ }^{39}$.

Powiązania finansowe między gospodarkami azjatyckimi spowodowały, że kryzys z 1997 roku był odczuwalny również — poza wymienionymi krajami — w chińskim systemie finansowym. W latach 1997-1998 zanotowano upadek jednego banku komercyjnego oraz trzech funduszy inwestycyjnych. W styczniu 1999 roku upadła zaś Guangdong International Trust and Investment Company — jedna z największych instytucji finansowych w kraju (drugi pod względem wielkości państwowy fundusz inwestycyjny), zostawiając 4,4 mld USD długu ${ }^{40}$.

\section{Kryzys nowego typu — dwa spojrzenia}

W literaturze daje się zauważyć co najmniej dwa główne podejścia do interpretacji zdarzeń kryzysowych z 1997 roku. W części prac ${ }^{41}$ wskazuje się na niską jakość instytucji sektora finansowego i nietrwałe fundamenty wzrostu gospodarczego jako główne źródła kryzysu azjatyckiego. Niedoskonałe regulacje bankowe, w tym dotyczące wymogów kapitałowych, słaby nadzór bankowy (na przykład w Indonezji), nieostrożna polityka kredytowa wynikająca przynajmniej częściowo z powiązań między sektorem bankowym a dużymi przedsiębiorstwami sektora realnego - kredytobiorcami (choćby w przypadku koreańskich czeboli) — to ważne elementy, które przyczyniły się do narastania nierównowagi, a także przeszkodziły we wcześniejszym zidentyfikowaniu zagrożenia. Benmelech i Dvir (2011) argumentują nawet, że wzrost krótkoterminowego finansowania dłużnego przed kryzysem azjatyckim 1997 roku był nie tyle samodzielną przyczyną załamania gospodarczego, ile symptomem słabości instytucjonalnych, które należy interpretować jako główne źródło kryzysu ${ }^{42}$. Podobna interpretacja znalazła się w badaniu z $2015^{43}$ opartym na modelu klasy DSGE, w którym badacze doszli do

39 A. Szołtun, op. cit.

40 M. Farley, Chinese investment firm gitic collapses, „Los Angeles Times” 12.01.1999, https:// www.latimes.com/archives/la-xpm-1999-jan-12-fi-62726-story.html (dostęp: 15.01.2020).

41 G. Corsetti, P. Pesenti, N. Roubini, Paper tigers? A model of the Asian crisis, „NBER Working Paper „NBER Working Paper Series” 1998, nr 6783.

42 E. Benmelech, E. Dvir, Does short-term debt increase vulnerability to crisis? Evidence from the East Asian financial crisis, „National Bureau of Economic Research. Working Paper Series” 2011, nr 17468.

43 L.E. Ohanian, P. Restrepo-Echavarria, M.L. Wright, Bad investments and missed opportunities? Postwar capital flows to Asia and Latin America, „NBER Working Paper Series” 2015, nr 21744. 
konkluzji, że w powojennej historii gospodarczej Azji oraz Ameryki Łacińskiej to wewnętrzne szoki były główną determinantą międzynarodowych przepływów kapitałowych. Szoki dotykające międzynarodowego rynku kapitałowego — zgodnie $\mathrm{z}$ wynikami badania - miały mniejsze znaczenie w kształtowaniu przepływów kapitałowych do poszczególnych krajów.

Jeśli chodzi o interpretację kryzysu azjatyckiego z 1997 roku w szerokim kontekście, to interesujące wydają się w szczególności artykuły Paula Krugmana i ewolucja jego spojrzenia na kryzys. W publikacjach z $1994^{44}$ oraz z 1997 roku $^{45}$ argumentował on, że główną słabością wschodzących gospodarek azjatyckich w latach dziewięćdziesiątych był zbyt kapitałochłonny wzrost. Do jego sfinansowania nie mogły wystarczyć oszczędności wewnętrzne, zwłaszcza że Azja Południowo-Wschodnia nie należała przecież do grupy krajów rozwiniętych. Różnica między nakładami na środki trwałe a oszczędnościami w gospodarkach azjatyckich (zaprezentowana na wykresie 4) rzeczywiście wskazuje na potrzebę finansowania zagranicznego, przed którą stanęły te kraje. Zwiększały się zatem nakłady inwestycyjne, co przyczyniało się do znacznego wzrostu gospodarczego. Za tym wzrostem nie szła jednakże odpowiednio duża poprawa wydajności ${ }^{46}$. Kraj uzależniający wzrost gospodarczy od importu kapitału zagranicznego i dodatkowo utrzymujący sztywny kurs walutowy może stać się przedmiotem ataku spekulacyjnego.

W późniejszych pracach ${ }^{47}$ Krugman zmienił interpretację kryzysu. Noblista przestał uznawać za główną przyczynę kryzysu kapitałochłonny wzrost przy braku odpowiedniej poprawy wydajności i słabości instytucjonalne (to jest korupcję i tak zwany kapitalizm kolesi ${ }^{48}$. Uznając w dalszym ciągu istotną rolę tych uwarunkowań, Krugman zwrócił uwagę na stopień otwartości gospodarek azjatyckich na międzynarodowe przepływy kapitału. Kraje azjatyckie w 1997 roku były podatne na panikę rynkową nie ze względu na słabości instytucjonalne, które występowały w tych gospodarkach od lat, ale ze względu na strukturę finansowania wzrostu, czyli otwarcie na przepływy kapitałowe ${ }^{49}$.

Krugman przyznał też, że funkcjonowanie inwestorów instytucjonalnych funduszy inwestycyjnych — oparte na koszykach krajów było najważniejszą przyczyną transmisji kryzysu między zróżnicowanymi gospodarkami azjatyckimi ${ }^{50}$. Ekonomista poddał również krytyce rekomendacje MFW wobec gospodarek do-

44 P. Krugman, The myth of Asia's miracle, „Foreign Affairs” 73, 1994, nr 6.

45 P. Krugman, What ever happen to the Asian miracle?, https://archive.fortune.com/magazines/fortune/fortune_archive/1997/08/18/230188/index.html (dostęp: styczeń 2020).

46 P. Krugman, The Myth...

47 P. Krugman, Will Asia Bounce Back...; oraz idem, Powrót recesji...

48 Ibidem.

49 Ibidem, s. 91.

50 Ibidem, s. 87. 
tkniętych kryzysem azjatyckim (politykę cięć budżetowych, wysokich stóp procentowych oraz likwidację nierentownych banków) ${ }^{51}$.

W ten sposób Krugman w swoich ocenach zbliżył się, jeśli chodzi o rozłożenie akcentów, do prac Radeleta i Sachsa ${ }^{52}$, a także Carletona, Rosarii i Woo ${ }^{53}$, a oddalił od innych istotnych badaczy kryzysu azjatyckiego, przede wszystkim Corsettiego, Pesentiego i Roubiniego ${ }^{54}$.

\section{Podsumowanie - cechy kryzysu azjatyckiego a potrzeba rozwoju krajowego rynku finansowego}

Niezależnie od ostatecznie przyjętej interpretacji kryzysu azjatyckiego analiza jego historii prowadzi do dwóch istotnych kwestii.

Po pierwsze, kryzys azjatycki z 1997 roku odznaczał się cechami, których nie miały wcześniejsze kryzysy walutowe. Tradycyjnie w literaturze ${ }^{55}$ wyróżnia się trzy generacje kryzysów walutowych: 1. kryzysy pierwszej generacji (model Krugmana) w latach siedemdziesiątych i osiemdziesiątych w Meksyku, Argentynie i Brazylii — łączone z błędami w wewnętrznej polityce gospodarczej; 2. kryzysy drugiej generacji (model Obstfelda) w latach dziewięćdziesiątych w krajach europejskich (Francja, Wielka Brytania) — łączone z czynnikiem zewnętrznym, to jest atakami spekulacyjnymi na waluty krajów pozostających w systemie ERM; 3. kryzys trzeciej generacji (tak zwany model eklektyczny) w krajach Azji Południowo-Wschodniej w 1997 roku.

Gospodarki azjatyckie nie doświadczyły problemów fiskalnych ani wewnętrznych problemów makroekonomicznych. Polityka makroekonomiczna wschodzących gospodarek azjatyckich przed kryzysem wydawała się właściwa, choć występowały pewne, zasygnalizowane już, słabości instytucjonalne. Ponadto na uwagę zasługują tempo i zasięg rozprzestrzeniania się zjawisk kryzysowych między różnymi gospodarkami ${ }^{56}$. Kryzys azjatycki należy rozpatrywać przez pryzmat wielu składowych. Rozpoczął się zasadniczo od kryzysu walutowego, który wybuchł w warunkach bańki inwestycyjnej między innymi na rynku nieruchomości. Potem przekształcił się w kryzys bilansu płatniczego i kryzys bankowy. Banki-rezydenci w gospodarkach azjatyckich były bowiem zadłużone w walutach ob-

51 Ibidem, s. 106-107.

52 S. Radelet, J. Sachs, op. cit.

53 P. Carleton, B. Rosario, W.T. Woo, The unorthodox origins of the Asian financial crisis: Evidence from logit estimations, „ASEAN Economic Bulletin”, special issue, April 2000.

54 G. Corsetti, P. Pesenti, N. Roubini, Paper tigers...; eidem, What caused the Asian currency and financial crisis? Part I: A macroeconomic overview, „NBER Working Paper Series” 1998, nr 6833.

55 I. Goldstein, A. Razin, Three branches of theories of financial crises, „Foundations and Trends in Finance" 10, 2015, s. 113-180.

56 J.K. Sudaram, op. cit.; P. Krugman, Powrót recesji... 
cych. Dlatego też deprecjacja waluty krajowej istotnie wpłynęła na ich koszty obsługi długu. Na skutek spadku eksportu oraz wzrostu kosztów obsługi długów zaciągniętych przez przedsiębiorstwa niefinansowe od nierezydentów wzrosło także ryzyko kredytowe sektora realnego. Banki doświadczyły zatem zarówno wzrostu kosztu zobowiązań, jak i spadku wartości aktywów ${ }^{57}$. W konsekwencji nastąpił kryzys bankowy oraz ogólny kryzys gospodarczy. Zestaw cech kryzysu azjatyckiego był zatem tak nietypowy w kontekście doświadczeń sprzed 1997 roku, że wydzielono go jako osobną kategorię.

Kawai i Rana (2009) wskazują również, że kryzys azjatycki był kryzysem bliźniaczym - zanotowano wystąpienie kryzysu bilansu płatniczego oraz kryzysu bankowego ${ }^{58}$. Nietypowe było natomiast to, że kryzys bilansu płatniczego dotyczył bilansu obrotów kapitałowych w większym stopniu niż obrotów bieżących. Zmianę we współwystępowaniu różnych rodzajów kryzysów przed 1997 rokiem w gospodarce światowej ilustrują badania Kaminsky i Reinhart z $1999^{59}$. Autorki na podstawie analizy pięciu gospodarek rozwiniętych oraz piętnastu wschodzących wskazują, że w latach 1970-1979 miały miejsce trzy kryzysy bankowe oraz dwadzieścia pięć kryzysów bilansu płatniczego, podczas gdy w latach 1980-1995 dwadzieścia dwa kryzysy bankowe towarzyszyły czterdziestu sześciu kryzysom bilansu płatniczego.

Po drugie, analiza źródeł kryzysu azjatyckiego (niezależnie od tego, którą z wcześniej omówionych linii interpretacyjnych uznamy za bardziej przekonującą) ujawnia potrzebę rozwoju krajowych dłużnych rynków finansowych w gospodarkach wschodzących czy szerzej - gospodarkach będących w fazie szybkiego wzrostu gospodarczego i w konsekwencji mobilizacji kapitału w walucie krajowej od rezydentów.

Cechą wspólną większości gospodarek azjatyckich dotkniętych kryzysem w 1997 roku było przechodzenie fazy szybkiego wzrostu gospodarczego i industrializacji opartych na eksporcie. W literaturze ${ }^{60}$ zwraca się uwagę, że faza industrializacji przypadła w gospodarkach azjatyckich na okres liberalizacji przepływów kapitałowych oraz liberalizacji systemu finansowego w ogóle. Przykład udanej industrializacji Europy Zachodniej po II wojnie światowej dotyczy okresu ograniczonej swobody przepływu kapitału. Podobnie Japonia, Korea Południowa, której relatywnie wysoki poziom rozwoju nie uchronił przed kryzysem w 1997 roku, oraz Tajwan rozpoczynały fazę industrializacji w warunkach ograniczonej mobilności kapitału.

57 M. Kawai, P. Rana, The Asian financial crisis revisited. Lessons, responses and new challenges, [w:] Lessons from the Asian Financial Crisis, red. R. Carney, New York 2008.

58 Ibidem.

59 G.L. Kaminsky, C. Reinhart, The twin crises: The causes of banking and balance-ofpayments problems, „American Economic Review” 89, 1999, nr 3, s. 473-500.

60 J.K. Sundaram, op. cit. 
Kraje azjatyckie, takie jak Tajlandia, Indonezja, Malezja, czy Filipiny, które wchodziły w fazę dynamicznego wzrostu gospodarczego oraz industrializacji w warunkach liberalizacji przepływów kapitałowych, były narażone na ryzyko nagłego odpływu finansowania. Ponadto realizując politykę sztywnego kursu walutowego, pozbawiły się możliwości aktywnego reagowania przy użyciu polityki pieniężnej na szok gospodarczy. Początkowa reakcja na kryzys wsparta rekomendacjami MFW także przyczyniła się do pogłębienia skali załamania gospodarczego. Pomijając kwestię niewłaściwej polityki gospodarczej tych krajów w szerokim kontekście, należy zauważyć, że w szczególności błędem było oparcie wzrostu gospodarczego na zagranicznym krótkoterminowym finansowaniu walutowym.

Poza wymienionymi aspektami przeprowadzona w niniejszym artykule analiza kryzysu azjatyckiego uwypukla znaczenie strategii inwestycyjnych. Podmioty krajowe, na przykład fundusze emerytalne, mogą być bardziej zainteresowane długoterminowymi inwestycjami w porównaniu do międzynarodowych funduszy inwestycyjnych. Ponadto inwestorzy krajowi więcej wiedzą o rynku wewnętrznym. W przypadku inwestorów krajowych nie ma też problemu automatycznych decyzji o wyjściu z finansowania danego przedsięwzięcia ze względu na kondycję sąsiednich gospodarek czy też gospodarek znajdujących się w tym samym koszyku inwestycyjnym.

Odpowiednio rozwinięte krajowe rynki finansowe, na przykład rynek obligacji przedsiębiorstw nominowanych w walucie krajowej, mogą i powinny być konkurencją dla zagranicznych, zwłaszcza krótkoterminowych źródeł finansowania dłużnego. Taka konkurencja otwiera szansę na pozytywną zmianę struktury napływającego kapitału zagranicznego. Historia kryzysu azjatyckiego pokazuje, że rozwinięte krajowe rynki finansowe są warunkiem koniecznym (choć niewystarczającym) do osiągnięcia zrównoważenia makroekonomicznego w fazie szybkiego wzrostu gospodarczego w gospodarkach wschodzących. Dywersyfikacja finansowania gospodarki, jeśli chodzi o pochodzenie środków (krajowe lub zagraniczne), może służyć podniesieniu jakości tego finansowania w rozumieniu Eichengreena, Hausmanna i Panizzy ${ }^{61}$, czyli redukcji podwójnego niedopasowania bilansowego, to jest wydłużeniu terminów wymagalności pożyczek oraz ograniczeniu niedopasowania walutowego.

\section{Bibliografia}

Alba P., Bhattacharya A., Claessens S., Hernandez L., Volatility and Contagion in a Financially-Integrated World: Lessons from East Asia's Recent Experience, PAFTAD 24 Conference Asia Pacific Financial Liberalization and Reform, Chiang Mai 1998.

Bank Światowy, Asia: The Road to Recovery, Washington 1998.

61 B. Eichengreen, R. Hausmann, U. Panizza, op. cit. 
Benmelech E., Dvir E., Does short-term debt increase vulnerability to crisis? Evidence from the East Asian financial crisis, „National Bureau of Economic Research. Working Paper Series” 2011, nr 17468.

Berg A., The Asian crisis: Causes, policy response, and outcomes, „IMF Working Paper” 1999, nr 99 (138).

Carleton P., Rosario B., Woo W.T., The unorthodox origins of the Asian financial crisis: Evidence from logit estimations, „ASEAN Economic Bulletin”, special issue, April 2000.

Chang C.-Y., Capital Flows, Financial Markets and Banking Crises, London 2017.

Corsetti G., Pesenti P., Roubini N., Paper tigers? A model of the Asian crisis, „NBER Working Paper Series" 1998, nr 6783.

Corsetti G., Pesenti P., Roubini N., What caused the Asian currency and financial crisis? Part I: A macroeconomic overview, „NBER Working Paper Series” 1998, nr 6833.

Corsetti G., Pesenti P., Roubini N., What caused the Asian currency and financial crisis? Part II: The policy debate, ,„,NBER Working Paper Series” 1998, nr 6834.

Eichengreen B., Hausmann R., Panizza U., Currency mismatches, debt intolerance, and original sin why they are not the same and why it matters?, [w:] Capital Controls and Capital Flows in Emerging Economies: Policies, Practices and Consequences, red. S. Edwards, Chicago 2004.

Farley M., Chinese investment firm gitic collapses, „Los Angeles Times” 12.01.1999, https://www. latimes.com/archives/la-xpm-1999-jan-12-fi-62726-story.html.

Goldstein I., Razin A., Three branches of theories of financial crises, „Foundations and Trends in Finance" 10, 2015.

Hoe Ee K., Wei Zheng K., Ten years from the financial crisis. Managing the challenges posed by capital flows, [w:] Lessons from the Asian Financial Crisis, red. R. Carney, New York 2008.

Kaminsky G.L., Reinhart C., The twin crises: The causes of banking and balance-of payments problems, „American Economic Review” 89, 1999, nr 3.

Kawai M., Rana P., The Asian financial crisis revisited. Lessons, responses and new challenges, [w:] Lessons from the Asian Financial Crisis, red. R. Carney, New York 2008.

Krugman P., Powrót recesji, przeł. [z ang.] M. Ruszczyński, Warszawa 2012.

Krugman P., The myth of Asia's miracle, „Foreign Affairs” 73, 1994, nr 6.

Krugman P., What ever happen to the Asian miracle?, https://archive.fortune.com/magazines/fortune/fortune_archive/1997/08/18/230188/index.htm.

Krugman P., Will Asia Bounce Back?, speech for Credit Suisse First Boston, Hongkong, 1998, http:// web.mit.edu/krugman/www/suisse.html.

Lai J., Financial Crisis and Institutional Change in East Asia, London 2012.

Mundell R.A., Capital mobility and stabilization policy under fixed and flexible exchange rates, „The Canadian Journal of Economics and Political Science” 29, $1963 \mathrm{nr} 4$.

Obstfeld M., Shambaugh J.C., Taylor A.M., The Trilemma in History: Tradeoffs among Exchange Rates, Monetary Policies, and Capital Mobility, Dublin 2004.

Ohanian L.E., Restrepo-Echavarria P., Wright M.L., Bad investments and missed opportunities? Postwar capital flows to Asia and Latin America, „NBER Working Paper Series” 2015, nr 21744.

Radelet S., Sachs J., The onset of the East Asian financial crisis, [w:] Currency Crises, red. P. Krugman, Cambridge, MA 2000.

Sławiński A., Dusza M., Kryzysy walutowe w krajach otwierajacych się na wymiane, „Materiały i Studia NBP" 1998, z. 70.

Sundaram J.K., Causes of the 1997-1998 East Asian crises and obstacles to implementing lessons, [w:] Lessons from the Asian Financial Crisis, red. R. Carney, New York 2008.

Szczukiewicz A., Przebieg i skutki kryzysu azjatyckiego końca XX wieku, [w:] Kryzysy światowe i recesje. Teoria, historia, przykłady, red. K. Piech, Warszawa 2012.

Studenckie Prace Prawnicze, Administratywistyczne

i Ekonomiczne 33, 2020

(C) for this edition by CNS 
Szołtun A., Systemy bankowe w Azji Poludniowo-Wschodniej, „Materiały i Studia NBP” 2002, Z. 114 .

Weisbrot M., Ten years after: The lasting impact of the Asian financial crisis, [w:] Ten Years After: Revisiting the Asian Financial Crisis, red. B. Muchhala, Washington 2007. 